\title{
Problems of democratic governance of civil-military relations in Turkey and the European Union enlargement zone
}

\author{
UMIT CIZRE \\ Bilkent University, Ankara, Turkey
}

\begin{abstract}
In the light of the pre-eminent role of the military in Turkish public affairs, this article seeks to assess critically the suitability of the entry criteria that Turkey must fulfil if it is to accede into the European fold. With that in mind, the article takes the idea of the 'democratic control of the armed forces' (Decaf), as conceived of by Western agencies such as NATO (North Atlantic Treaty Organization), OSCE (Organization for Security and Cooperation in Europe) and the EU (European Union), and unravels its relevance and implications for the Turkish case. The key features of Central and Eastern European systems of civil-military relations, which are targeted by the Decaf measures are contrasted with the Turkish case in order to show that a single-model approach to Decaf is untenable. It is then argued that the way that the strategy that has been used for implementing Decaf is impoverished because it fails to capture the 'real politics' in which militaries are embedded. Based on that, the article reaches the conclusion that one of the central factors preventing Turkey's potential accession into the European fold is the prevailing civil-military relationship. However, the approach being employed by Western agencies fails to adequately recognize and respond to the nature of that relationship.
\end{abstract}

Over the past decade, Turkish politics has been confronted with two conflicting developments. On the one hand, the Turkish military structure has placed far greater emphasis on its self-appointed role as guardian of the basic principles of the Turkish state. On the other hand, the European Union (EU) has prescribed a package of political preconditions that must be fulfilled if Turkey is to gain successful entry into the European fold. While the military's overseer role by definition requires that it remains the pre-eminent source of authority in Turkey, the underlying implication of the EU's entry criteria is that the military structure must be subordinate to democratic control.

If one of the basic features of Turkey's parliamentary democracy since 1950 has been the formidable presence of the military in public affairs, the other has been the regime's longstanding commitment to being identified as 'European'. While the conjoining of these two missions - namely, the 'guardian' and 'vanguard' roles - is not particularly subtle or unprecedented (see, e.g., Pye 1962; Halpern 1962; and, for Turkey, Horowitz 1981: 42), it is unusual in a region where militaries have had neither the will nor the 
wherewithal to safeguard the status quo or spearhead reform. This article, in part, addresses the issue of reconcilability between the guardian and vanguard roles of the Turkish Armed Forces (TAF) in view of the threshold shift in its objectives since its last intervention into politics on 28 February $1997 .{ }^{1}$ The inherent tension that exists between the two roles has been heightened over the last decade as the more conservative inclinations of the military have gained ascendancy over its more reformative inclinations.

The main instrument effecting the military's expanded influence over Turkey's political development and its autonomy from civilian actors has been the redefinition of the 'national security concept'. Internal political discord has been re-interpreted in the language of internal security threats. Hence, Islamic activism and Kurdish nationalism were singled out as internal security threats and given primacy over the external ones. By virtue of the threat posed by such internal enemies, the military high command defends the view that the expansion of freedoms in Turkey represents too high a price to pay to in order to be accepted into the European fold. ${ }^{2}$ Instead, the military hierarchy argues that its fight against Islamic extremism is sufficient proof of its allegiance to the Western world. Thus, the TAF has expanded the scope of its guardianship mission by securitizing the country's serious, but essentially political problems and, as a result, has distanced itself even further from its vanguard mandate. This is largely made possible by letting the national security concept influence codification of laws pertaining to internal security, anti-terrorism, maintenance of public order, political activities and public debate, and by expanding military jurisdiction over civilians. It is the translation of national security into laws, decrees and regulations that in fact gives the Turkish military a wide latitude in policy making and law enforcement.

The problem with this justification of the military's enlarged guardianship role is that the so-called 'internal security problems' may in fact be the result of the extant civil-military imbalance. If so, then the TAF's justification of its greater domestic involvement and independence from democratic checks and balances is both self-fulfilling and self-perpetuating. Indeed the very nature of the civil-military imbalance means that the military has almost exclusive control over the definition of what qualifies as being within the remit of national security in the first place. That leads us to ask whether the threshold shift reflects the corporate interest of the military structure rather than a concern for the common interest of the Turkish Republic. Indeed, as Ben Lombardi suggests, the generals may have to 'consider a paradox, the possibility of international isolation fomented by western states as a consequence of seeking to save Atatürk's republic' (Lombardi 1997:211). Would the Turkish military want to be part of a political bloc in which the prioritization of peace, human rights, fundamental freedoms and a democratic system of civilian 
control over the TAF would endanger its institutional interests and its political influence? The answer can hardly be an unconditional 'yes'. In order to survive as the primary interlocutor in politics, the military hierarchy probably opts for a process of entry into the EU that is under its close supervision and control.

The growing contradiction between the military's two self-assigned mandates is mirrored in the tension that exists between its increased influence over public affairs and the preconditions that must be fulfilled if Turkey is to gain formal acceptance into the European fold. Those preconditions imply the view that militaries should be professionally strong against external threats, but politically weak with regard to internal public affairs. In other words, militaries, at least with regard to internal affairs, should be subject to democratic control.

Against the background of the historical pre-eminence and, recently, the changing role of the Turkish military, this article's primary concern is to unpack and critically assess the idea of the 'democratic control of armed forces' (henceforth 'Decaf'). Decaf has been formulated by Western agencies as a political precondition to be fulfilled by those post-communist countries in the enlargement zone of NATO (the North Atlantic Treaty Organization) and the EU. However, the Decaf prescription is also relevant for Turkey given that it is a candidate country waiting to be given full member status by the EU. As part of the accession process, the European Commission has been assessing Turkey's progress based on the fulfillment of the political criteria set out in the Copenhagen European Council meeting of 1993. ${ }^{3}$

The Copenhagen Criteria, as they are now known, require the implementation of institutional stability, complete freedom of expression, the entrenchment of human rights, respect and protection for minorities, and an efficient market economy. Although civil-military relations are not explicitly referred to in the Criteria, the spirit of the document is that there should be a rethinking of the extent to which the military structure is independent of democratic control. Moreover, in the annual reports of the European Commission on Turkey, certain institutional areas of civil-military relations are specifically marked out as requiring reform. Perhaps the clearest expression of the European Commission's view on this issue comes in its most recent report published in November 2001: 'The basic features of a democratic system exist in Turkey, but a number of fundamental issues, such as civilian control over the military, remain to be effectively addressed' (EC 2001: 97). Indeed, as we shall see, the EU's ongoing reports (EC 1998, 1999, 2000a, 2001) on Ankara's accession progress have suggested the need for structural changes in the organization of civil-military relations in order to enhance civilian control and to bring the institutional structure in line with EU standards. 
Against the Turkish background, this article delves into the theory and practice of Decaf in two ways. First, the central features of the Central and Eastern European (C\&EE) conception of civil-military relations - which the Decaf measures are primarily designed to improve - are contrasted with the Turkish case. The adequacy of implementing in Turkey the same model of Decaf as in the post-communist states is called into question given that the Turkish military's institutional, legal, moral and popular grounds for watching over the regime are formidable and because Turkey is already integrated into the Western collective security framework. Second, it is argued that the organizing principles underlying the idea of Decaf are impoverished insofar as they disregard the context in which the military structure is embedded. The upshot of this is that Decaf underestimates the magnitude of the task that is required if a democratically accountable military is to be realized in Turkey.

\section{Decaf in the Central and Eastern Europe, Balkan and Baltic states and Turkey: One model fits all?}

Although the priority areas for reform of the military are different in each of the transition countries, there seems to be a rough consensus on the organizing principles that lie behind Decaf. Namely, a clear constitutional division of authority between the civil and military sectors, parliamentary control of the defense budget and, in order to ensure its political neutrality, governmental discretion over the professional, institutional and political activities of the military. When the elements of this consensual definition are brought together, ${ }^{4}$ Decaf amounts to executive control over military activity and parliamentary supervision of both the government and military (Sarvas 1998: 2; see also Bebler 2000: 3).

Since the end of the Cold War, democratic and civilian control of the military has turned into a common priority of NATO and its PfP (Partnership for Peace) partners. Similarly, it has also climbed high on the European agenda of integration, European identity-building, good governance and security. Decaf is conceived of as consolidating and institutionalizing a democratic model of civil-military relations whereby military subordination to civilian authority is accepted as the norm. However, underpinning this presumption is that 'there is a recognizable model of civil-military relations [that] discounts other models' (Forster 2001: 10).

The context and structures that enforce Decaf are inextricably linked with the process called 'enlargement' (i.e., shifting the borders of NATO and EU eastwards and southwards), which entails fundamental changes for the 
prospective entrants if they are to adapt themselves to the entry requirements. Since 1993-1994, Decaf has become part of the criteria to qualify for membership in the EU, the WEU (Western European Union) and NATO. It has, in other words, turned into a political precondition for the C\&EE states so as to ensure democracy and regional security.

The objective of wanting to establish a system of Decaf in the C\&EE states is to preclude the potential threat of a politically powerful military intervening in politics. These states are assumed to be crisis-ridden transition countries exhibiting 'peripheral' features in that they are socio-economically and politically behind the advanced capitalist societies of the West. As the armed forces are still considered to be the key players in politics, and therefore capable of praetorian-style military intervention, enlargement turns into a Western security interest. Hence, it is thought that Decaf is a critical instrument for promoting stability and peace in 'not-quite' democracies and in the presence of 'politicized' militaries. Underlying this is the assumption that, in the enlargement process of NATO and the EU, the expectation of membership in these organizations is the strongest motivation for necessary reforms, helping to stabilize democracy in the C\&EE states (Verheugen 2001: 5). The post-September 11 trend towards greater European integration to promote security has enhanced the importance of Decaf as a strategic instrument.

The Accession Partnership drawn up for Turkey in 2000 is said to be 'modeled on the regulation for the ten Central and Eastern European countries' (EC 2000b: 5). However, I will argue that the choice of the C\&EE countries as the model for Turkey's accession to the EU is misguided from both a policy and a methodological point of view. As the playing fields between those two contexts are significantly different, the roadmaps for accession must also be taken as markedly different. Perhaps with that issue in mind, the EU Commission proposed a compromise strategy in 1999 (adopted by the European Council in Nice in December 2000). Although accession negotiations should be opened with all the remaining candidate countries that have already fulfilled the Copenhagen Criteria (i.e., democracy, the rule of law, human rights and respect for and protection of minorities), the door should be left open so that latecomers can catch-up. However, this change addresses the technicalities of the accession process rather than the theoretical objections to the 'one-size fits all' approach to Decaf. I will argue that the context that the Decaf model presumes does not pertain to the Turkish context. A single model derived from the experiences of the post-communist states simply 'misses the target' when applied to the Turkish case. 


\section{Mismatch I: Different militaries, different sources of legitimacy}

There are differing assessments of the civil-military system at work in postcommunist countries. One group of researchers speaks of the potential threat of a politically intrusive military by virtue of the fact that Soviet military heritage is deeply embedded in the psyche of the C\&EE's officer corps: '[T]he Communist Party's long influence over the military cannot simply be eliminated through legal measures, by abolishing certain institutions and establishing new ones. Democracy itself is a process and profound changes take time to take root' (Szemerkenyi 1996: 79). Soon after 1989, the threat of military involvement in politics was distinctly possible in Czechoslovakia, Poland and Hungary. So much so that the order of priority was to first depoliticize the army and then to secure the military's loyalty to the new governments and cut all ties with the former Warsaw Pact (Szemerkenyi 1996: 74-75). On the other hand, some argue that the idea of the military being politically controlled was not a new phenomena in the post-1990 period, and that even though the civilian sphere lacked sufficient information, resources and expertise, 'the legal framework for civilian oversight of the military is by and large complete in Central Europe' (Szemerkenyi 1996: 20). Indeed, in the area of overseeing the implementation of the defense budget and the acquisition of military equipment, the level of civilian control 'has been most successful' (Szemerkenyi 1996: 27).

In very general terms, compared to the Turkish case, the militaries in the C\&EE states are smaller in size, weaker in terms of force levels, underdeveloped in corporate identity, low in political profile and non-interventionist with regard to domestic politics. On this last issue, it is widely acknowledged that for most of the countries of post-communist Europe, the military has historically lived by the principle of staying out of politics. Rather, the historical record is one of Communist Party control of the military institution. What then prompts Western agencies to launch Decaf policies is that the process of transition itself, rather than pre-existing conditions, might motivate the military to become involved in politics (Edmunds et al. 2001:4). Nevertheless, the potential of a praetorian military (undoubtedly the primary concern of Decaf) in the C\&EE states is low and perhaps even entirely lacking largely because the 'armed forces are politically divided (Russia), they lack legitimacy (Hungary, the Czech Republic), and do not wish to impose military ways upon society (Romania, Bulgaria) and/or (with the conspicuous exception of Russia) do not want to spoil their country's chances of becoming NATO members' (Callagan \& Kuhlmann 2000: 14). In addition, 'when the civilmilitary experiences of C\&EE states in the past ten years are considered, one of the fundamental problems in this area has not been military interference 
in domestic political matters, but lack of defense and security expertise or misinformed and inept civilian management of the security sector issues' (Cottey et al. 2000: 9).

In marked contrast to the ideology and practice of the military structure in C\&EE, the TAF takes full advantage of its self-appointed and legally recognized $^{5}$ guardianship mandate. As the Turkish Republic was founded by a civil and military bureaucracy, the TAF entered the new republic in 1923 with a pervasive sense of its own prerogative to watch over the regime it created. Moreover, it has perpetuated its historical pre-eminence by controlling the fundamentals of the political agenda while remaining beyond parliamentary control. An important upshot of this is that while the post-communist states have had to construct a civil-military institutional framework from scratch - as in Lithuania, Latvia, Estonia and Slovenia, for example (for Slovenia, see Bebler 2000: 30) - similar reforms in Turkey must take place in spite of a long-established and deeply-rooted tradition of civil-military relations. According to that tradition, the military maintains a privileged position in society vis-à-vis non-military groups insofar as it is able to initiate and veto policy without any meaningful checks and balances being imposed by the constitutionally elected governments of the country (Sakallıg glu 1997). In other words, the military constitutes itself as a legitimate actor in political decisionmaking; an institution that is entitled to promote different ideas about democracy, public life and national security than that held by the elected representatives.

The features that are shared by C\&EE's militaries, however, are centered on the legacy of their subordination both to the communist ideology and to the Communist Party as the carrier of that ideology. This model of civil-military interaction is diametrically opposed to the guardianship model: for instance, the most significant Decaf measure regarding C\&EE has been to ban political parties from working within and recruiting from the military (Sarvas 1998: 5). However, a quite different trend is apparent in Turkey. The military initiates and exerts pressure on the political class, the public and the judiciary in the direction of banning political parties when it deems they operate against the foundational pillars of the republic. More importantly, the model defies the democratizing trend in post-Cold War militaries and civil-military relations in former communist countries.

This brings us to the next source of the legitimacy for TAF's guardianship role - namely, the huge support it garners from within Turkish society. By contrast, the military in the former communist states suffers from a distinct lack of popular support, no doubt a hangover from the recent past (Vlachova 2000: 22). The real secret behind TAF's continuing domination in Turkey lies not in its role of guarding the republic coercively, but in the more subtle form of 
power relations that it has successfully developed with the Turkish public to evince consent and approval through seemingly non-repressive methods. The key conduits for disseminating and inculcating the military ideology within the officer corps is the military schooling system; similarly, within the civilian realm, compulsory military service and the re-crafting of reality by a conservative-nationalistic education system and media. In this way, the Turkish military has played a role in successfully hardening mass perceptions of the observance of secularist principles in the public sphere and on any democratic opening for a Kurdish voice in Parliament. It would be wrong, on the other hand, to disregard completely the contribution made by the failure of the civilian political class in the 1990s to effectively manage the country's key problems.

All in all, the TAF is careful not to give any signs of relinquishing its guardianship role, even after the 1999 Helsinki Summit's decision to announce Turkey's candidacy for the EU. The Summit, for the first time in the EUTurkey relationship, explicitly laid down rigorous standards (the Copenhagen Criteria) by which its political, legal and military institutions can be judged. ${ }^{6}$ If the guardianship role is epitomized in a military's propensity to make or break governments, the TAF's potential power to do so is beyond any doubt and does not at all seem to be a passing phenomenon. Utilizing Luckham's (1971) seminal typology, it is possible to assert that by proving its capacity to submerge itself beneath the surface and yet be able to support a long-term political order, the TAF has always maintained the basic characteristics of the 'covert guardianship' model.

\section{Mismatch II: International security designs and domestic civil-military reform}

The priority of Decaf in the C\&EE context has become the need to provide the conditions for integration into the Western security framework. By contrast, Turkey has already been part of that structure for a number of years, thus suggesting that the priority of Decaf in that case should be establishing the internal conditions for civilian control over the military. Again it seems that the presumptions that lie behind the application of Decaf in the post-communist countries do not fit the conditions that exist in Turkey.

In almost all of the countries in C\&EE, Decaf covers two security policy goals: reforming the defense establishment, and reorienting foreign and security policies to aid integration into Western security structures (Szemerkenyi 1996: 75). However, changes in external conditions and the objectives of Western agencies since the end of the Cold War have played a large role in 
influencing the balance between these two goals in the post-communist states. It is argued that before the PfP was launched in 1994, the chief concern in Western political circles was to promote a democratic change in civil-military relations by way of institutional reforms (Szemerkenyi 1996: 64-65). However, in 1993-1994, as Decaf became a fundamental requirement for NATO enlargement and for membership of the EU and WEU, the primary emphasis of NATO and PfP shifted from support for democratization to enabling integration into Western security structures. That shift of emphasis arose partly because PfP's priority areas were military and technical, implying an emphasis on the requirements of the military structure rather than civilians (Szemerkenyi 1996: 67). More significantly, the view that Decaf's priority should be enlargement and integration was given added impetus by the election success of the military-backed former communists in some C\&EE states in the mid-1990s (Szemerkenyi 1996: 75-76). As a result, the Decaf concept was no longer understood by Western agencies as primarily an instrument through which to promote democracy. Rather, the priority was, in view of the threat of the rise of the political left with the military behind it, to establish external control over the militaries by co-opting them into the West security structure.

However, as Turkey has been a staunch member of NATO since 1951, it makes more sense to interpret Decaf in terms of the political criteria required for membership in the EU. With regard to the Turkish position on Decaf, therefore, it appears to be more relevant to speak of the entry requirements of the EU rather than NATO. As a reliable NATO ally, a bulwark against the spread of radical Islam, located strategically along trans-regional fault lines in the Balkans, Caucasus, Eurasia and Middle East, Turkey has the largest standing army in NATO after the United States, and a strong military community. This situation is an invaluable asset to NATO and the United States, a fact that was further proven in the aftermath of the September 11 attacks in New York and Washington. The anti-terrorist alliance being assembled by Washington's initiative in this new period reaffirms Turkey's ongoing determination to exploit its geopolitical importance and military assets through its membership of NATO. The gathering emphasis on enabling a collective military response to the new security challenges (i.e., terrorism, secessionist movements, and civil, ethnic and religious wars, and so on) strengthens the Turkish establishment's claim to prioritize military preparedness over reform of the civil-military balance. The question is whether international/Western considerations for Turkey's new role in the post-Cold War era provides a legitimate basis for sustaining its preoccupation with 'hard' security concerns and a strong military culture and machine. The risk involved here is that a politically and morally powerful military can use military preparedness and capability as an 
instrument to enhance further its internal and external status. Indeed, the cooperative security concept is well received by Turkey's military-dominated security community. ${ }^{7}$

The trajectories of the Turkey-EU relationship, however, do not bear out a similar perception of a geopolitically important Turkey. This is in spite of the fact that Turkey's security-conscious civil and military bureaucrats base their arguments for entry into the EU on the grounds that: 'Turkey offers Europe an extended depth against the risks of western military defense, missiles and instabilities. Turkey's partnership can help Europe to protect stability in a periphery that is most troublesome. There, Turkey can hold the military balances in favor of Europe' (Ergüvenç 1998: 67). Despite the selfperception that 'Europe's shortcomings in military capabilities might render Turkey's role...more meaningful and even indispensable' (Ergüvenç 1998: 66), what the EU seems to be pushing for is not a militarily strong Turkey, but a democratic and prosperous Turkey that would exercise a liberalizing and civilizing influence in the region. Therefore, the political clout of the TAF seems to be one of the reasons why the EU is unwilling to accept Turkish entry.

Another much-ignored problem concerning external/international pressure for internal reform is the question of how it is that Turkey, with its 50year membership of NATO, has not received the necessary impetus to democratize its civil-military relations? Turkey's history with NATO does indeed weaken the thesis that NATO membership helps to spread the reformative norms of Decaf by either making it a condition of membership or by increasing intergovernmental contacts between member militaries (Reiter 2001: 57, 58-59). One explanation for the Turkish situation is that NATO's overarching political objective was containment of the Soviet Union during the Cold War, which was implemented at the expense of democratization for the then peripheral countries such as Greece, Spain, Portugal and Turkey. While there was greater tolerance for the democratic shortcomings of NATO members during the Cold War, by the end of the 1980s, when politicalmilitary relations had become a key condition for C\&EE militaries to enter into the NATO fold, 'the dominant role of the military in Turkey, a longstanding NATO member, has proved perhaps more worrying' (Roper 1999: 99).

Unlike the C\&EE context, therefore, security integration does not appear to be the suitable reading of Decaf in the Turkish case. This, combined with the fact discussed in the previous section that Turkish civil-military relations are characterized by an engrained tradition of covert guardianship, suggests that the post-communist states provide a entirely inappropriate basis for determining how Decaf should be implemented in Turkey. 


\section{The poverty of the Decaf approach}

\section{Bringing the history back in}

Leaving aside the discrepancy between the C\&EE and Turkish contexts, a more fundamental concern with the idea of Decaf is that it is basically a Western-liberal conception of civil-military relations. By holding up the postcommunist states to standards derived from the historically unique experiences of the non-communist West, the concept is vulnerable to the charge of both reductionism and ahistoricism. Decaf may be accused of trying to impose a universally valid model of civil-military relations over the whole European continent. If we accept that the civil-military interface is built on 'particular ideas that have evolved into principles, norms and rules embedded in institutions and reinforced by history, experience and prejudice' (Bland 1999: 16), then the notion has to be sensitive to the historical realities that form the foundations of a particular civil-military configuration. Thus, transferring the Decaf prescription into divergent topographies will generate an understanding of Decaf that is different both in substance and scope than the ones that pertain in the liberal West.

In order to circumvent the simplistic approach of Decaf, there are two issues that need to be solved in the struggle to establish civilian oversight over any non-Western military. First, the specific conditions that provide the motives and pretexts for a military establishment to undermine civilian supremacy must be properly understood. Second, it should be clear that the crucial problem is not just the implementation of Decaf, but also the larger one of 'civilian empowerment' - that is, to enable civilian governments to take control over not only the military universe, but also the life of the country, the economy, political process, institutional make-up, justice system and foreign relations. However, attempts to establish a stronger civilian role in dealing with problems of governance cannot succeed unless it is accompanied by two simultaneous changes: a genuine engagement with these plans on the part of the military itself and a deeper change in the prevailing public philosophy.

\section{A civilian- or military-centered Decaf?}

Once 'civilian impotence' is recognized in some contexts as a major obstacle standing in the way of establishing the political and professional subordination of the armed forces, and if Decaf is to be saved from being merely a list of institutional norms with little or no practical significance, a distinction must be made between 'civilian-centered' control by which civilians 'deliberately monitor the military's behavior and exclude them from various undertakings' 
(Hunter 1994: 634) and 'military-centered' control which is 'designed to induce the military to adopt an apolitical or non-interventionist outlook of their own accord' (Hunter 1994: 634). Hunter, working on Argentina, Brazil and Chile in the 1990s, comes to the conclusion that in countries where militaries have had a long record of political intervention and have not abandoned guarding the national interest, civilian-centered politics cannot be expected to bring in the necessary results (Hunter 1994: 635). The Turkish experience fully supports Hunter's assessment that the current process of Decaf promotion in those areas of the world with a history of an interventionist army can only be achieved if the military in question is brought into the picture through critical dialogue, constructive engagement and 'shared responsibility, rather than control' (Bland 1999: 10).

Moreover, it might be argued that that the notion of civilian control in a democratic system of civil-military relations lacks sufficient subtlety because it assumes a clear-cut division of labor between the civil and military sectors. This cuts against the post-Cold War trend where militaries get entangled with civil governance of the military because of the new reality of blurred distinctions between politics and military spheres. As new realities have changed the basic security requirements, the participation of military elites in many parts of the West in defense and security policy making has become more palatable to politicians as well as to the public, 'albeit as junior partners, in the decision-making process at the highest levels with regard to issues of doctrine and the use of force' (Boene 1998: 98). Civilian control under the new reality is at best conditional and dependant on the attitudes and traditions of the military that should be allowed to have a degree of rightful and vested authority over its internal matters, strategic issues and military doctrine. With regard to the uncertain distinctions between civil military domains in C\&EE and Turkey, for instance, protecting the political structure from military intervention should also be one objective of Decaf. A concurrent goal is obviously to protect the political abuse of military power by insecure and incompetent politicians.

It seems reasonable that in establishing a civilian direction for the military in contexts like Latin America where military involvement is pervasive, Decaf remains at bottom a question of creating an environment for the military in which it affirms the democratic principles of civilian control. Reconstructing an environment for Decaf, however, may also mean reshaping the terms of debate by moving from the control aspect of the civil-military interface to the good governance or empowerment issues regarding the civilian sphere.

One obvious question that follows from this is what should be the source of civilian empowerment. According to Stepan (1988: 144), effective control of the military 'requires an effort by civil and political society to empower 
themselves to increase their own capacity for control'. Empowerment of political, civil and economic society is seen as the essential stage in the process of improving government performance and creating a political climate where the military considers subordination to civilian authority as the only justified course of action.

\section{Institutional bias}

The institutional bias of Decaf reflects the increasingly 'linear' character of the post-Cold War understanding of modernization. Historical progress for accession to the EU is marked out by stages through which all the candidate states must pass. The EU's preoccupation with institutional standards is based on an understanding that the Reflection Group of the Forward Studies Unit of the European Commission aptly puts as: "what unites "Europe" of the EU is not so much a common substantive "European culture" and "European values", but commitment to these basic rules and procedures' (Reflection Group 1999: 35). This conception is implemented in accordance with the procedures that qualifies one for membership, rather than acquiring or having a European identity.

The central problem with this procedural approach is that mere institutional reform of civil-military relations will often fail to identify and respond to an underlying web of unspoken and maybe invisible systems of sustenance that legitimize the military's ability to influence. As Decaf is about creating a new military culture with a newly instilled respect for civilian control where the ideological and historical underpinnings of the power relationship must undergo substantial change, what is required is more than just a list of institutional reforms, amendments to existing laws, and the constitution or the promulgation of new laws.

Turkey is a classic example of Decaf being understood and applied in a purely institutional way. The EU's Regular Report of 2000 explicitly puts the issue of Decaf in Turkey in institutional terms: 'a number of basic institutional issues, such as civilian control over the military remain to be addressed' (EC 2000a: 21). In all the EU originating reports and documents on Turkey, there are four strictly institutional areas that are targeted for reform: the position of the Chief of General Staff, the role of the National Security Council, the composition and jurisdiction of the State Security Courts, and the emergency rule in the Southeast. These are used to identify whether or not the civil-military balance is shifting towards civilian control (see EC 1998, 1999, 2000a, 2001). Thus, on the question of the Turkish Chief of General Staff being responsible to the Prime Minister rather than the Defense Minister, for example, the 1998 Regular Report notes that: the army sometimes even 
appears to act without the Government's knowledge when it carries out certain large-scale repressive military operations' (citing the evidence that in 1997, two operations by the Turkish Armed Forces (TSK) against the bases of the PKK in northern Iraq took place without the Chief of General Staff giving the Government any prior notice) (EC 1998: 11). Similarly, the Accession Partnership Document of 2000 also calls for the lifting of the state of emergency in the Southeast, under which governors of the provinces surrender their powers on public order to the regional governor (EC 2000b: 11). However, when positive legal changes are made in any of these areas of concern, these documents recognize that there is progress regardless of any assessment of whether or not the change is translated into a less militarized political environment and outlook in the country. It should be noted that even according to the EU's strictly institutional reading of Decaf, Turkey is still not considered to have met the Copenhagen Criteria as restrictions on the exercise of fundamental freedoms remain and civilian control over the military has not been established (EC 2001: 97).

The EU reports do occasionally show signs of recognizing the paucity of an approach that focuses exclusively on the design of institutions and the distribution of power between them. Thus, the 1999 Regular Report, while recognizing the importance of the replacement of the military judge by a civilian one in the State Security Courts in the wake of Öcalan's trial, concedes that: 'through the NSC [National Security Council], the military continues to have an important influence in many areas of public life' (EC 1999: 10). Similarly, according to the 1998 Regular Report: 'the existence of this body [NSC] shows that despite a basic democratic structure, the Turkish Constitution allows the Army to play a civil role and to intervene in every area of public life' (EC 1998: 13-14). The same Report identifies the sources of the increased parameters of the power of the NSC as non-institutional emanating from recent developments in administration and the education system which, 'while intending to strengthen secularism, nonetheless underline the particular role of the military in Turkish society' (EC 1998: 9).

However, the Regular Report of 2000 returns to the proceduralist paradigm by arguing that the major problem with the NSC is its influence over the Government and its 'little accountability to the parliament with regard to security and defense matters' (EC 2000a: 12). The remedy suggested is to increase the number of civilian members of the Council. Given that Turkey's NSC is not just a body established for defense and security issues, but also for the preservation of the official ideology (Jenkins 2001: 46), the strictly institutional diagnosis of the problem and the remedy suggested is insufficient. Indeed over the last decade, the reach of the NSC in politics has extended over areas formally considered the responsibility of civilian authority. This has been 
achieved by singling out Kurdish and Islamic issues as security priorities. Significantly, the NSC's expanded role has occurred in spite of the external pressure to institutionally reform, and in spite of any actual reform that has taken place.

After the composition of the NSC was modified (as part of the constitutional amendment package of October 2001) so as to make the civilian members the majority and limit its role to one of recommendation, the Regular Report of 2001 still registers dissatisfaction with the fact that its de facto power and reach remains the same (EC 2001:19) and states the need to monitor 'the extent to which the constitutional amendments will enhance de facto civilian control' (EC 2001: 19). If this is so, the EU itself appears to be conceding that a purely institutional approach - in this case increasing the number of civilian members of the council - is a largely ineffectual means of achieving Decaf. The high command, being perfectly aware that the voice of the military cannot be altered just by changing the composition of the Council, has supported the idea of including more civilian ministers into its folds. It is also cognizant of the fact that the dominance of the military view in the NSC is born out of the significantly unequal power relationship between the military and the civilian sides of the NSC. The civilian component is more reticent than the military component not because of any physically imposed limits on their participation, but probably due to self-imposed restraint. The internal urge not to arouse the antagonism of the military has always been the most powerful brake. The 1998 Regular Report's proposal to 'align the constitutional role of the National Security Council as an advisory body to the government in accordance with the practice of EU member states' (EC 2000b: 11) thus seems to be marked with an insufficient understanding of the cultural, political and ideological weight of the military in Turkish life.

What this suggests is that interpreting Decaf in purely institutional terms ignores the root causes of its absence. For behind the fundamental tenets of the concept lies an understanding of militaries as ideology-free and purely defensive institutions with no corporate spirit, no history, and no ideological and alliance capabilities to help them retain societal support and political prerogatives. This view does not capture the 'real politics' in which militaries are embedded. Rather it appears to presuppose the political and cultural conditions that tend to apply in Western democracies. Thus, institutional improvements in countries such as Turkey may simply disguise the underlying power structure. If so, those who overawe the civil-military relationship can pay lip service to the notion of Decaf by accepting institutional reform in the safe knowledge that their pre-eminence is not actually threatened. 


\section{Acknowledgements}

A draft version of this article was presented at the IUS (Inter-University Seminar on Armed Forces and Society) Biennial International Conference at the University of Maryland-Baltimore, USA, 19-21 October 2001, in the workshop on 'The Renaissance of Democratic Control of Armed Forces in Europe? One Model of Democratic Control Fits All?'. I would like to extend my gratitude to those participants who took part in the discussion, and in particular to Dr Hans Born for his very constructive criticisms.

\section{Notes}

1. On this last occasion, the military-dominated National Security Council (Milli Güvenlik Kurulu) handed down to the constitutionally elected coalition Government of the day a 20-point list of measures to clamp down on 'reactionary Islam' ('irtica' in Turkish) that forced Prime Minister Necmettin Erbakan (the leader of the pro-Islamic Welfare Party that led the coalition with Tansu Çiller's the True Path Party) to resign.

2. For a representative statement of the military's view that accepting the accession requirements should be based on some conditions, see 'AB Zorunlu Ama ...' ['The EU is Essential but ... . Milliyet, 10 October 2000.

3. In the Luxembourg Summit held on 12 December 1997, the EU turned down Turkey's application for full membership on the grounds of its tarnished record on fundamental rights, mostly incurred as a result of fighting a war to protect its internal security against Kurdish and Islamist groups. In the Helsinki European Council meeting of 10-11 December 1999, this decision was reversed as a consequence of a series of positive turns, including the rapprochement between Turkey and Greece after the August 17 earthquake in 1999 and Washington's decisive pressure on the EU. The Helsinki Summit called for opening accession negotiations with six countries, but decided that Turkey would benefit from a pre-accession strategy to support the same reforms as the other candidate countries. Negotiations with Turkey would not start until Ankara fulfilled the political conditions for accession explicitly framed at the Copenhagen European Council meeting in 1993 and embodied by the Amsterdam Treaty of 1994.

4. According to Edmunds et al. (2001: 4), Decaf should also involve democratic control of defense and foreign policy areas. Greene (2000: 10) adds the dimension of civil societal control to the legislative and executive oversight. In addition, he argues that for C\&EE setups there is a particular need for parliamentary discussion not only on the budget, but also on security threats and policy, and their translation into military strategy and tactics. This is presumably not because armies leave their imprint on national security policy making in the way the TAF does, but in order to increase the number of legislators who have some knowledge of how security policies are made.

5. Turkish constitutions have not openly proclaimed any guardianship role for the military. However, developments and some provisions of Act No. 2945 pertaining to the National Security Council and the National Security Council General Secretariat combine to assign significant and broad political powers to the National Security Council, placing it on par with the executive branch of the government. Legislation on anti-terrorism, public 
order, the media, political parties and rules on the internal regulation of the armed forces also enshrine this national security concept. In addition, Article 35 of the Military Internal Service Code assigns the military the task of safeguarding Turkish territory and the Republic as defined by the Constitution. This Article has been invoked on each occasion the military intervened in politics. Moreover, governance through 'emergency rule' as the basic instrument of managing the Kurdish problem has played a significant role in enhancing the political parameters of the military. Finally, the military bureaucracy's autonomous intelligence and surveillance functions and jurisdiction over crimes against internal security and terrorism also reaffirm its position in Turkish politics and is reflected in its autonomy from parliamentary oversight in its budget and internal affairs.

6. Soon after the Helsinki announcement, e.g., the TAF issued open statements to the effect that it would not consider being answerable to the Defense Ministry instead of the Prime Ministry. The high command also rebutted press reports about officers who were expelled from the armed forces for their Islamic tendencies being allowed to appeal to the civilian courts. See 'Domestic News Summary', Turkish Daily News, 24 January 2000.

7. Turkey's participation in NATO-led peacekeeping missions is seized upon as an opportunity to show the superior capability and availability of the TAF to its European counterparts and to internal public opinion. At the time of writing this article, Turkey has a brigade in Bosnia. Ankara has also contributed to the Multinational Protection Force in Albania and KFOR together with an F-16 squadron based in Italy as part of NATO's Stabilization Force (SFOR). In addition, participating in joint military operations serves as a public relations exercise to enhance the internal profile of the TAF and increase its regional influence. In the bilateral arena, Turkey has forged a security partnership with Israel, which, among others, helps Turkish military's modernization program.

\section{References}

Bebler, A. (2000). Civil-military relations and democratic control of armed forces in Slovenia, 1990-2000. Paper presented at the 7th Biennial Conference of ERGOMAS, Prague, 6-10 December.

Bland, D.L. (1999). A unified theory of civil-military relations. Armed Forces and Society 26(1): 7-26.

Boene, B. (1998). Trends in the political control of military institutions in the post-Cold War era. Paper presented at ERGOMAS Conference on the Political Control of Military, Stockholm, 24-27 September.

Callaghan, J. \& Kuhlmann, J. (2000). Civil control of the military. Paper presented at ERGOMAS Working Group Meeting on 'Democratic Control of Armed Forces' at the 4th International Security Forum held by the Geneva Center for Democratic Control of Armed Forces, 15-17 November.

Cottey, A. et al. (2000). The second generation problematic: Rethinking democratic control of armed forces in Central and Eastern Europe. Available online at: http:// civil-military.dsd.kcl.ac.uk.

EC (1998). Regular Report 1998, from the Commission on Turkey's Progress Towards Accession. Brussels: Commission of the European Community.

EC (1999). Regular Report 1999, from the Commission on Turkey's Progress Towards Accession. Brussels: Commission of the European Community. 
EC (2000a). Regular Report 2000, from the Commission on Turkey's Progress Towards Accession. Brussels: Commission of the European Community.

EC (2000b). Accession Partnership Document Turkey: 2000. Brussels: Commission of the European Community.

EC (2001). Regular Report 2001, from the Commission on Turkey's Progress Towards Accession. Brussels: Commission of the European Community.

Edmunds, T. et al. (2001). Rethinking civil-military relations, democracy: Lessons from Central and Eastern Europe. Paper presented at the IUS Biennial International Conference, Baltimore, 19-21 October.

Ergüvenç, S. (1998). Turkey's strategic importance in military dimension: A regional balance holder. In M. Aydin (ed.), Turkey at the Threshold of the 21st Century. Ankara: International Relations Foundation.

Forster, A. (2001). New civil-military relations and its research agenda. Paper with ESRC award number L213 25 2009. London: ESRC.

Greene, O. (2000). Democratic accountability of the security sector (ESRC Working Paper). Available online at: www.civil-military.dsd.kcl.ac.uk.

Halpern, M. (1962). Middle Eastern armies and the new middle class. In J.J. Johnson (ed.), The role of the military in underdeveloped countries. Princeton, NJ: Princeton University Press.

Horowitz, I.L. (1981). Military origins of Third World dictatorship and democracy. Third World Quarterly 3(1): 37-47.

Hunter, W. (1994). Contradictions of civilian control: Argentina, Brazil and Chile in the 1990s. Third World Quarterly 15(4): 633-653.

Jenkins, G. (2001). Context and circumstance: The Turkish military and politics (Adelphi Paper 337). London: International Institute for Strategic Studies.

Lombardi, B. (1997). Turkey: The return of the reluctant generals. Political Science Quarterly 112: 191-215.

Luckham, A.R. (1971). A comparative typology of civil-military relations. Government and Opposition 6(1): 5-35.

Pye, J. (1962). Armies in the process of political modernization. In J.J. Johnson (ed.), The role of the military in underdeveloped countries. Princeton, NJ: Princeton University Press.

Reflection Group (1999). The long-term implications of the EU enlargement: The nature of the new border. Final report of the Reflection Group set up jointly by the Forward Studies Unit of the European Commission and the Robert Schuman Centre, European University Institute, Florence, chaired by Guiliano Amato.

Reiter, D. (2001). Why NATO enlargement does not spread democracy? International Security 25(4): 41-67.

Roper, J. (1999). The West and Turkey: Varying roles, common interests. The International Spectator 34: 89-102.

Sakallığlu, Ü.C. (1997). The anatomy of the Turkish military's autonomy. Comparative Politics 29(2): 151-166.

Sarvas, S. (1998). The shift from the transitional to democratic agenda: Problems and future of democratic control of armed forces in the Czech Republic. Paper presented at the 6th Biennial Conference of ERGOMAS on Building a New European Soldier, Stockholm, 24-27 September.

Stepan, A. (1988). Rethinking military politics: Brazil and the Southern Cone. Princeton, NJ: Princeton University Press. 
Szemerkenyi, R. (1996). Central European civil-military reforms at risk (Adelphi Paper 306). London: International Institute for Strategic Studies.

Verheugen, G. (2001). Speech in the European Parliament on EU enlargement, Strasbourg, 4 September.

Vlachova, M. (2000). Democratic control of armed forces in the Czech Republic: The way out of isolation. Paper presented at the ESRC Conference on Civil-Military Relations and Defense Planning: Challenges for Central and Eastern Europe in the New Era, Kiev, 24-27 March.

Address for correspondence: Umit Cizre, Department of Political Science, Bilkent University, 06533 Bilkent Ankara, Turkey

Tel.: +90 31226648 71; Fax: +90 31229027 42; E-mail: umit@bilkent.edu.tr 